Review Essay

\title{
Fifty Years of Reaction and Reform: American Catholicism and the Second Vatican Council
}

\section{Karen Park}
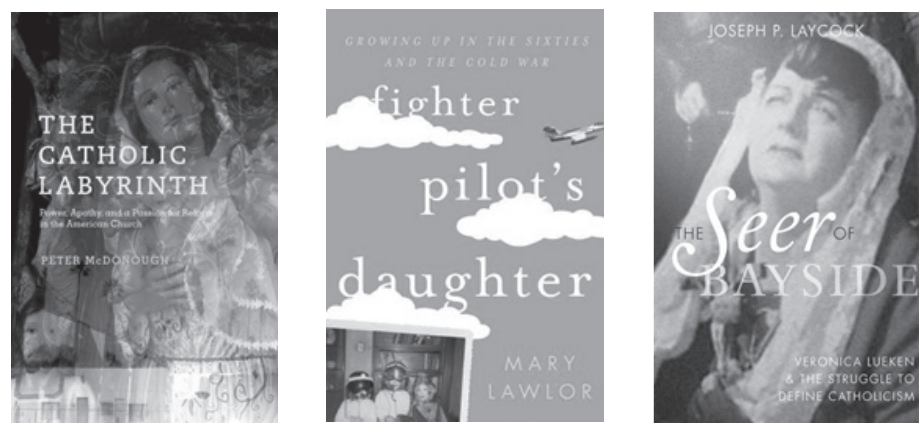

THE CATHOLIC LABYRINTH: Power, Apathy, and a Passion for Reform in the American Church. By Peter McDonough. New York: Oxford University Press. 2013.

FIGHTER PILOT'S DAUGHTER: Growing up in the Sixties and the Cold War. By Mary Lawlor. New York: Rowan and Littlefield. 2013.

THE SEER OF BAYSIDE: Veronica Lueken and the Struggle to Define Catholicism. By Joseph P. Laycock. New York: Oxford University Press. 2015.

2015 marks the fiftieth anniversary of the close of the Second Vatican Council, a watershed in the history of the Catholic Church and in the lives of 
millions of American Catholics. With regard to almost every aspect of Catholicism as it is lived and practiced, there was a before Vatican II and there is an after. Convened in October 1962 and closed in December 1965, the Second Vatican Council systematically organized, defined, and interpreted the totality of the faith - something that had not been done since the Council of Trent, the major council held in response to the Protestant Reformation in the sixteenth century. This time, however, there was no major crisis (such as the earth-shattering fact of Protestantism) to address. In fact, Pope John XXIII's announcement that he would convene a full council, something that had only been done twenty times in the history of Christendom, came as a total surprise even to his closest advisors. Pope John XXIII (Angelo Roncalli), who has recently been canonized, was a kindly pastoral and elderly man of seventy-seven when he became pontiff. All assumed that he would be an interim figure after the long pontificate of Pius XII. But instead John XXIII called for aggiornamento, updating, famously wanting to "throw open the windows of the Church," letting in both light and air. Liturgically, aesthetically, devotionally, socially, even sacramentally, the Catholic Church after Vatican II became a radically and fundamentally different place from which to view both this world and the next. The three books in this review, which come from the varied genres of personal memoir, religious studies, and political science, are each concerned with describing the disorientation and struggle for identity which has come to define Catholicism in America as the faithful wrestle with the changes of Vatican II as part of other societal changes and upheavals which have taken place simultaneously.

The more than 2,500 bishops who comprised the Second Vatican Council met from September through December for four consecutive years, from 1962 to 1965. When John XXIII died just one year into the council, his successor, Paul VI took up the mantle immediately and led the council to its completion. In addition to the thousands of bishops in attendance, several hundred lay observers were invited to sit in on the proceedings: Lutherans, Methodists, and even women. The openness of the Council, and of the pope who convened it, was something that had not been seen before and the world took notice. Life magazine, in its April 1963 story on the opening of the council, proclaimed, "The most amazing new force in world affairs is that simple, friendly, unpretentious man, the Pope of Rome . . . In 1958, John XXIII set in train a series of events which have since moved that huge old galleon, the Roman Catholic Church, back into the mainstream of world history and have profoundly altered the silhouette it presents to mankind."1

The purpose of the council, as articulated many times by its key players, was not to reform the Catholic Church but rather to renew it by leading it to both cooperate with and operate as part of the modern world. The sixteen documents that came out of the Council - four constitutions, three declarations, and nine decrees - did, however, change the Church in profound ways. Sacrosanctum Concilium (On the Liturgy), one of the four Constitutional documents, declared the Church to be the People of God and as such articulated the necessity of full 
participation of the laity in the sacred liturgy. Implementation of this document led to dramatic liturgical changes including the priest and congregants facing one another, the use of the vernacular instead of Latin in the Mass, and the reception of the Eucharist in the hands instead of directly into the mouth. Another of the Constitutions, Lumen Gentium, articulated an openness about the possibility of salvation extra ecclesia for non-Catholics and even non-Christians. Although the Church has always maintained that Vatican II should be interpreted in continuity with pre-conciliar times, and did not in fact represent a break with the past, the drastic changes felt, looked, and sounded like a break to many Catholics. And indeed it is hard to argue with evidence such as the statement taken from Pius IX's Syllabus of Errors in 1864 that "It is an error to say that adherents of any religion can find the way of eternal salvation and obtain eternal salvation" and the statement from the Vatican II constitutional document Lumen Gentium exactly one-hundred years later that, "Those also can attain to everlasting salvation who through no fault of their own do not know the Gospel of Christ or his Church, yet sincerely seek God and, moved by grace, strive by their deeds to do his will as it is known to them through the dictates of conscience." These changes - salvation available to all, changes to the liturgy and each of the sacraments, updated music, modern architecture and art, the relaxation of the magisterial restraints on the priests and nuns which led in part to the exodus of both men and women from the consecrated life, and the de-emphasis on para-liturgical devotional practices (like the Rosary) which had been the foundation of the lived faith of Catholic people - were adopted so rapidly that for many American Catholics it seemed the church they knew and loved had been whisked out from under them with no warning and no preparation.

Indeed, there was no systematic rollout of the changes of Vatican II in the US. Each diocese and oftentimes each parish made its own changes and then immediately implemented them. For many this was cause for rejoicing, but for others it was deeply distressing. As a child of the 1970s, I never experienced the pre-conciliar church of my parents and grandparents. My childhood was one of guitar masses and down-to-earth nuns named Sally and Mary Ellen. My parents, who had met in college during Vatican II and who had as children experienced the beauty but also the oppression of the pre-conciliar Church, were thrilled with the changes and had the advantage of discussing them and their theological implications with their Jesuit professors at Marquette University. But my grandparents, the children of Polish immigrants, felt displaced and saddened by the losses Vatican II entailed for them, never quite adjusted, and remained leery of masses held in gymnasiums on folded chairs and the other massive changes they experienced in the last decades of their lives.

Mary Lawlor's memoir of growing up in a Catholic military family during the 1950s and 1960s gives her readers a deep look into the patriotic household of a young midcentury American Catholic family. Lawlor is a professor of English and American Studies at Muhlenburg College and is recognized for her scholarship on the American West. Fighter Pilot's Daughter is a personal 
memoir, not a scholarly book, though it is informed by her keen historical understanding of the American social and political landscape. The book presents us with a detailed portrait of the fears, preoccupations, and uncertainties of the Cold War era as experienced from inside the American Cold War military. As an officer's child, one of four daughters, Lawlor's family moved constantly from base to base. By the time she graduated from high school she had attended at least fourteen schools. Her father, frequently absent on missions, spoke during his visits home of terrifying threats faced by America which could take the form of sudden invasions or even nuclear annihilation, and Lawlor grew up understanding that constant vigilance was necessary to secure American liberty and freedom. Half-knowledge and unspoken fears ruled Lawlor's Cold War childhood as she explains "[we] were told again and again that liberty, the exclusive property of America and its friends, was and always would be held up by its own, natural strength. This strength had to be cared for . . . That's what our fathers did. They took care of liberty" (3). Life as the daughter of a Cold War fighter pilot, who flew for both the Marine Corps and the Army, was filled with tension - both personal and existential - and the overall strength of Lawlor's book is the way in which it conveys, through personal recollection and deep family research, the personal side of the tensions that gripped American society during the Cold War.

The insular Catholic Church of the pre-conciliar era was, in many ways, well suited to the fortress mentality of the Cold War. Indeed the Cold War afforded American Catholics new ways to demonstrate their patriotism and American bona fides within a distinctly Catholic framework. Devotion to the fierce and protective figure of Our Lady of Fatima became ubiquitous among Catholic Americans during the 1950s, and praying the Rosary was understood as a powerful secret weapon for defeating Communism. For Lawlor, Russia loomed not as a distant or vague concept but was personified as an actual threatening presence (106). As Lawlor puts it, her family's culture was nurtured by the interlocking and overlapping categories of the Army, the Catholic Church, and Cold War patriotism. When she astutely observes that "None of these institutions supported independent self-making, although it was curious how they all claimed to exist to defend just that kind of independence" (126) she is putting her finger on a major tension in American life - the use of cultural and institutional conformity to defend liberty and independence.

The book is lengthy and somewhat wordy at times. Lawlor is giving us, as much as she can, the full picture of her childhood lived at the epicenter of the Cold War, but there is still a sense of distance between the reader and the subject matter. We are not really drawn into Lawlor's world, we stand at a distance, which is perhaps appropriate given the context of firm social, political, and religious boundaries she draws for us. Despite its length, overall Lawlor devotes relatively few words to the spiritual dimensions of her family's story. She seems to understand her family's mid-century Irish Catholicism as a matter of culture, part of the background or the fiber of the family, but not its most salient feature. 
But religion, in particular the drama and liturgy of pre-Vatican II Catholicism nevertheless played a big part in Lawlor's coming of age. During her early adolescence, while a student at Carmel Mission School in California, Lawlor began to feel a powerful "calling" to become a nun - a call that was common among young Catholic women of the pre-conciliar era and has become increasingly rare ever since. Her descriptions of the beauty and mystery of the Catholic experience and of the security that the consecrated life offered are among the best parts of the book. Lawlor allows us to understand why a modern American girl living in California in the 1960s could be drawn to join a celibate order of women. She skillfully articulates the ways in which the temptations of emerging sexuality and the temptations of Communism, secularism, and other forms of worldliness were intertwined and kept at bay by the "old" Catholic Church.

Tensions in Lawlor's family increase as the years go on, reflecting in the domestic sphere the turmoil of the country. Through Lawlor's telling of her family's story, it is possible to imagine more fully the ways in which the security of the pre-conciliar Catholic Church seemed suddenly to reveal itself to be as vulnerable to the sweeping forces of change as every other institution of the time. Lawlor's father, hoping to shield her from the anti-war movement, allowed her to go to college in Paris, where before long she changed from a bookish girl with conservative social and political leanings to a young leftist working against the draft and the Vietnam War. News of her involvement in the May riots of 1968 reached her father while he was stationed in Vietnam. He went to Paris to find her and bring her back to the military base in Germany, and their angry and contentious meeting forms the climax of the book. While not specifically attuned to the changes of Vatican II, Lawlor's memoir allows us to feel and imagine what was at stake during those years, and how the certainty of an American, Catholic, and patriotic worldview revealed itself to be anything but certain by the end of the 1960s.

When read within the context of the personal issues at stake during the Cold War/post-Vatican II period provided by Lawlor, Joseph P. Laycock's excellent book on a Marian visionary movement in Queens becomes even more persuasive and illuminating. The Seer of Bayside: Veronica Lueken and the Struggle to Define Catholicism is a compelling account of the Marian seer Veronica Lueken, who began receiving visions of Mary at her home in Bayside, Queens while praying fervently for Robert Kennedy's recovery from what would, of course, be a fatal gunshot wound. Between 1968 and her death in 1995, Veronica Lueken would receive thousands of messages from Mary, Jesus, and various other saints, becoming the controversial center of a community of traditionalist Catholic followers, the "Baysiders." Laycock understands the history of Veronica Lueken and her Baysider movement as "a series of contests over who has the authority to articulate a religious group's core tradition" (7). The changes of Vatican II, in full swing by 1968, play a large part in the story of the Baysiders' struggle to both articulate and fight for truth. Influenced by the work of various theorists from J.Z. Smith, to Benedict Anderson, to Victor 
and Edith Turner, Laycock understands Catholicism as an imagined community and the Baysider movement as a moment where the imagined boundaries of Catholicism did not hold firm.

Lueken's frequent and dramatic prophetic visions and the supernatural Polaroid photos that became associated with her vigils and communication with divine personages attracted many followers, among them great numbers of traditionalist Catholics whose Church now seemed to make no sense to them. Busloads of pilgrims and sometimes unruly crowds vying for a chance to see the visionary and hear her messages from Mary and Jesus disrupted both her parish community, St. Robert Bellarmine's, and her quiet and affluent neighborhood of Bayside, where the vigils were held before they were forcibly moved to Flushing Meadows Corona Park, site of the 1964 World's Fair. Eventually both the Bayside prophecies and Lueken's status as a visionary were condemned by the local bishop, at which point the determination of who could claim the authority to decide what is the true Church and on what grounds became crucial.

Lueken's prophecies, like the warnings of many visionaries, revealed a profound anxiety about the current state of the world. Social and cultural changes, especially those having to do with gender, sexuality, and technology (particularly the dangers posed by television) preoccupied the Baysiders. But perhaps the worst threat they faced was the aggiornamento of Vatican II, which shook the Baysiders' understanding of Catholicism to its core. For example, the new vernacular Mass and especially the receiving of Eucharist in the hand were understood as ritual transgressions, the latter a gesture of profound disrespect to the real presence of Christ, an act of ritual uncleanness that could not be tolerated by any good Catholic. Along with this, many Baysiders felt acutely the loss of traditional Catholic devotional culture, a source of deep comfort and meaning to millions, but which, in the spirit of Vatican II, was now being discouraged and dismissed as outmoded and embarrassing.

Once they were condemned by the Bishop, in a hasty investigation during which the Baysiders themselves were never consulted or questioned, the movement entered into a difficult relationship with the hierarchy, what Laycock calls a dance of defiance and deference, wherein respect for the authority of the Church hierarchy, the very place from which their deepest truths were being condemned, needed to be maintained. Although she was condemned and therefore an outsider, unlike other Catholic separatist movements that arose in wake of Vatican II, Lueken urged her followers not to leave the Church holding tightly to the prophecy that one day "the Mother Church will come around" (9) and the reforms of Vatican II will be reversed. The Baysiders also believed that Pope Paul VI, John XXIII's successor, was an imposter, “a communist doppelganger created by plastic surgery" (5), while the real Pope was being held prisoner by conspirators hoping to bring down the Church. Through beliefs and prophecies like this, the Baysiders have been able to understand themselves not in rebellion against the Church, but as perhaps its truest and most faithful members. 
I appreciated Laycock's reluctance to classify the Baysiders as a "New Religious Movement" (NRM) and to instead evaluate and engage with them on their own terms. He is honest and candid throughout about his own biases and tendencies, as when he feels conflicted about being invited to pray the Rosary while observing a Baysider vigil as a scholar, albeit a Catholic one. His analysis of sacred space, the negotiation of power as it is constantly re-imagined and reframed among and between groups, and the way in which he takes this strange movement and makes it familiar, all lead me to highly recommend this book to scholars of American religion as well as anyone interested in issues of power, sacred space, and the negotiation of these in American religious life. Laycock's book is concise, and is a welcome addition to the growing body of scholarship on American Catholicism.

The final book in this essay is Peter McDonough's The Catholic Labyrinth: Power, Apathy and a Passion for Reform in the Catholic Church. While Lawlor's book provides a personal context for the Cold War/Vatican II years, and Laycock's examines in depth one particular religious movement which arose in response to Vatican II, McDonough's book is much more broad and ambitious than either. Through meticulous research and original analysis, McDonough's work attempts to explain how the Catholic Church has changed in the years following Vatican II. His approach, while systematic, is not linear or unifocal. On the contrary, he takes a multi-faceted approach explaining that The Catholic Labyrinth is "about change in American Catholicism in the way that a cubist painting of a guitar is about a guitar" (14). In other words, the picture he paints of this change is not a singular image, but a series of overlapping and complex components that form a somewhat fragmented whole. Because some paths lead nowhere and others branch off in myriad directions, Catholicism after Vatican II is best understood as a labyrinth of ideas both complementary and competing.

The strength of this approach is its honesty and refusal to oversimplify. The weakness is the sheer chaos of the whole topic makes the book hard to read. McDonough does his best to alleviate this problem of which, no doubt, he is aware. He frequently explains to his readers what he is going to say before he says it, and even advises at one point in the introduction that we might feel free to skip ahead to Chapter Three, "where the narrative really begins" (3). But for those who are interested in the state of American Catholicism since Vatican II and who struggle to understand the complexity of the modern Church, there is much to think about here.

One of McDonough's main observations is that the aggiornamento and ecumenism of Vatican II did not simply roll on smoothly in the direction of modernity, openness, and progress in part because of the concomitant sexual revolution and its loosening of restrictive prohibitions on moral behavior (especially for women) and reproduction. Both the introduction of birth control pills in 1965 and the legalization of abortion by the Supreme Court in 1973 provided huge incentives for traditionalist Catholics to find common ground across devotional lines. In other words, Vatican II gave Catholics permission to reach out to 
their Protestant counterparts, but when they reached out the issues that brought them together had more to do with sex than justice. Chapters Three and Four in particular do an excellent job describing the neo-conservatism of the postVatican II Church and the reasons for its successes. This includes, according to McDonough, the fact that widespread fear of relativism and "ontological laissez faire" resonated with Catholics and conservative Protestants alike, as they surveyed the American social and cultural landscape together. "Family values" and "moral clarity" became coded, emotionally-laden terms that allowed Catholics and Protestants to join forces on moral issues without having to deal with the doctrinal differences that had kept them firmly separated in the past.

In parts III, IV, and V, McDonough surveys several progressive movements in American Catholicism, looking closely at specific groups like SNAP (Survivors Network of those Abused by Priests), FutureChurch, Voice of the Faithful, and the Leadership Roundtable. Here he finds varying levels of success when it comes to reform. SNAP, for example, with its adversarial approach to the Church hierarchy's struggles to articulate a way forward, seems stuck in a desire to name and expose. McDonough's optimism about the success of other groups with less adversarial and more cooperative stances, like the Leadership Roundtable, is tempered by his unflinching statements about the Church's pervasive "gender apartheid" and what he repeatedly calls the "wretched demographics of the priesthood" (196). Unless changes are made with regard to the makeup of the priesthood, all reform movements, no matter how temperate or sophisticated, will face insurmountable obstacles.

In his conclusion, McDonough asks "What has endured in American Catholicism since the 1960s? What has changed?" (271). He finds that very little has remained the same other than the continued grounding of the Church's identity in the inviolable rule of a male celibate clergy and the subordination of women. McDonough observes, rightly, "the sexual canon has barely yielded ground" (271). On the other hand, almost everything else has changed dramatically. The separation of Catholic institutions like hospitals and colleges from their founding orders and charisms is very nearly total. There are startlingly few priests and nuns left at all, almost none in parochial education. And while the church hierarchy has remained firm on issues of sexual morality, liberalization of sexual norms has largely succeeded anyway, the result of "a multiplicity of individual decisions swept up in a cultural tidal wave" (273). And the futurewhat kind of Catholic Church will survive into the twenty-first century and beyond? It is hard to say, because McDonough finds the divide between those who love the church and those who feel betrayed by it "so stupefying that it destroys reflection capable of making headway" (300). Certainly Veronica Lueken and the Baysiders would agree.

In conclusion, this unusual trio of books, organized loosely around the theme of the fiftieth anniversary of Vatican II, provides a varied set of perspectives and insights about the watershed event, the mystery and sense of security that preceded it, and the disillusionment and chaotic search for both personal 
liberty and universal truth that followed. While Mary Lawlor's Catholic military family was a place where the difference between good and evil was sharply drawn, it was also a place of oppression and fear from which she had to break free. Veronica Lueken and the Baysiders found in the apparitions and prophecies of the Virgin Mary a way to negotiate the difficult terrain of the postVatican II church and the sexual liberation of the 1960s and 1970s, though the path was often very difficult. McDonough makes astute observations regarding rampant gynophobia in the Church, which explains Veronica Lueken's treatment by the male hierarchy of her diocese; her story illustrates McDonough's excellent point that there is always a tinge of "male hysteria about the crazy lady in the attic of Catholicism" (33). And McDonough's book, far ranging as it is, provides a valuable resource for thinking about the seemingly intractable situation of the Church today, as progressives and traditionalists clash again and again over authority, ethics, and economics. McDonough has surveyed a vast and complex landscape and managed to map it, if only partially, which is itself an accomplishment worth celebrating.

Since the close of the Vatican II era and the death of John F. Kennedy, the country's only Catholic president, American Catholics have moved from a staunchly Democratic voting bloc to one that splits nearly evenly along party lines. This split can be attributed in part to the differences between Democrat and Republican positions on issues of sexuality and reproduction. In 1968, abortion was not an election issue for either side. But by 1976, the first post-Roe v. Wade presidential election, Jimmy Carter found himself scrambling to convince conservative Catholics that Democrats took their moral concerns about abortion seriously. The then Archbishop Joseph Bernardin of Cincinnati (later the Cardinal of Chicago) praised Republicans that year for their support of a Constitutional amendment banning abortion and criticized Democrats' opposition to the amendment. ${ }^{2}$ Culturally conservative Catholics now overwhelmingly vote Republican, numbers that have increased steadily since the 1970s. McDonough's observations about the sexual revolution and its impact on the reforms of Vatican II have also been borne out in the U.S. Supreme Court's approach to issues of sexuality and reproduction (there are currently six Catholics that sit on the court). The court's ruling in Burwell v. Hobby Lobby Stores (2014), which determined that a private corporation owned by a religious family is not required to provide contraceptive coverage under the Affordable Care Act, was praised by the United States Council of Catholic Bishops (USCCB) and many other American Catholic leaders. The American Catholic leadership's nearly exclusive focus on issues of gender and reproduction is clear, especially when one considers that these same groups remained virtually silent on the Harris $v$. Quinn ruling - handed down by the Supreme Court at the same time-which weakened labor unions, support for whom had previously dominated Catholic social teaching in the pre-Vatican II era. American Catholics today remain equally divided on the issue of abortion, but have dramatically increased their 
support for gay marriage with 67 percent of Catholics now favoring or strongly favoring gay marriage, a figure that has gone up 25 percent since 2003 . $^{3}$

All of the books reviewed here were written before the pontificate of Francis, who, more than any other figure, now embodies the spirit of Vatican II. From the earliest days of his papacy he has described the Church not as a pyramid, hierarchy, or fortress but as a "field hospital after a battle." ${ }^{4}$ He was just a young seminarian in 1965, but far more than his predecessors, Francis has carried the pastoral aims of John XXIII into his understanding of the pontificate and the Church as a whole. It remains to be seen whether what many describe as Francis's revitalization of the spirit of Vatican II will take root, or what direction the Church will go in after him, but when that time comes we may begin our analysis from a rich field of inquiry, in part due to the resources I have discussed here.

\section{Notes}

2. For more on this demographic shift see William B. Prendergast, The Catholic Voter in American Politics: The Passing of the Democratic Monolith (Washington, DC: Georgetown University Press, 1999) and Kristin E. Heyer, Mark J. Rozell, and Michael A. Genovese, eds. Catholics and Politics: The Dynamic Tension between Faith and Power (Washington, DC: Georgetown University Press, 2008).

3. Robert P. Jones, Daniel Cox, and Juhem Navarro-Riviera. “A Shifting Landscape: A Decade of Change in American Attitudes about Same-sex Marriage and LGBT Issues." Washington, D.C.: Public Religion Research Institute. Accessed online at http://publicreligion.org/site/wp-content/ uploads/2014/02/2014.LGBT REPORT.pdf, 10.

4. Antonio Spadaro, S.J., "A Big Open Heart to God," America Magazine, September 19, 2013, 24. This lengthy interview was remarkable for the ways in which Pope Francis admitted his own sinfulness and frailty, the mistakes of his past, and his understanding of the sanctity of the common people. In this interview he also signals and openness and acceptance of homosexual personas and stated, with regard to abortion, contraception, and gay marriage that "it is not necessary to talk about these things all the time" (ibid., 26). 


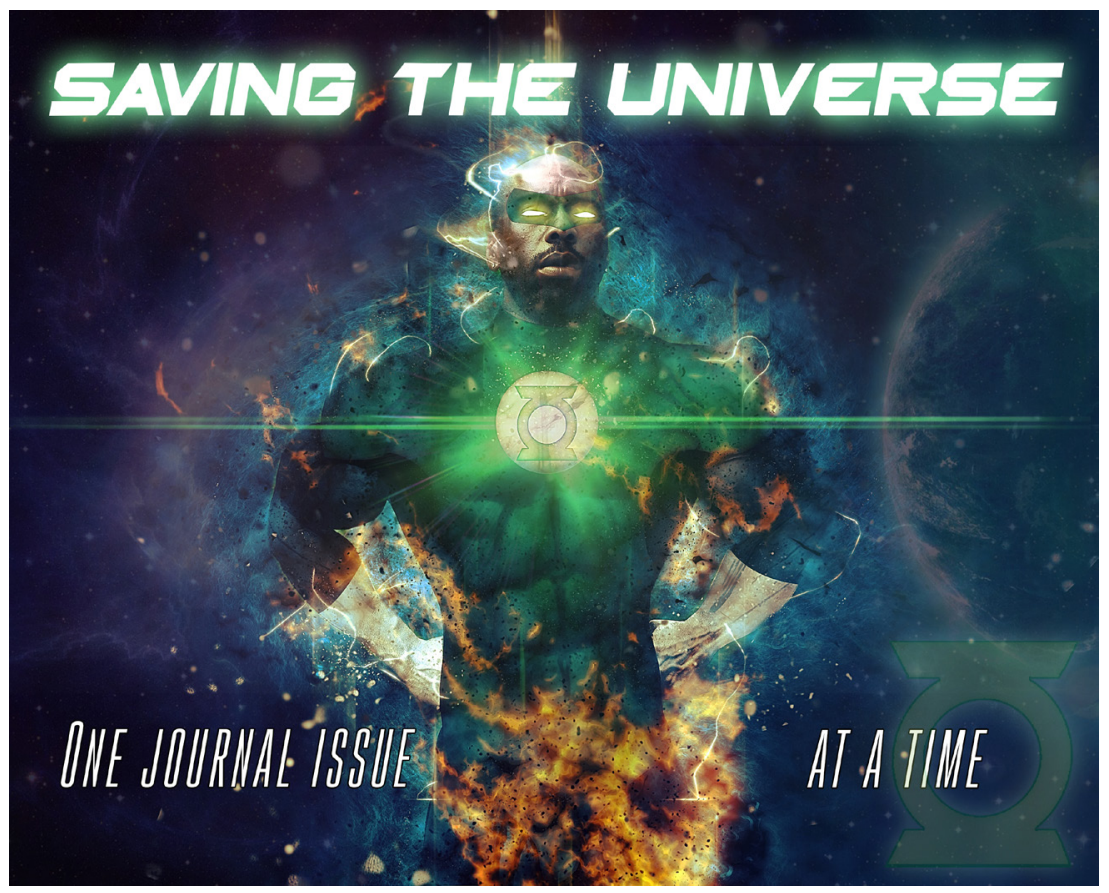

Davarian Baldwin, editorial board member, as the Green Lantern. Photo by VisionMerge Productions. 